\title{
EFFECT OF SEEDING RATES ON YIELD AND YIELD COMPONENTS OF TWO BREAD WHEAT CULTIVARS
}

\author{
Dalia A. A. EL Hag \\ Agronomy Dept., Faculty of Agric., Kafrelsheikh University
}

\begin{abstract}
Two field experiment were conducted in 2012/13 and 2013/14 growing seasons at Faculty of Agricultural- Kafrelsheikh University to study the effect of four seeding rates on yield and yield components of two bread wheat cultivars. This study was laid out in a split plot design with three replications. Wheat cultivars, Sids 12 and Misr 1 were allocated in the main plots. The four seeding rates, 200, 250, 300 and 350 seeds $/ \mathrm{m}^{2}$ were randomly assigned in the sub plots. The studied trait were: days to heading, days to maturity, grain filling period, grain filling rate, plant height, flag leaf area, number of spikes $/ \mathrm{m}^{2}, 1000$-kernel weight, number of kernels/spike, grain yield, straw yield and harvest index. The results indicated that Misr 1 recorded the highest values for days to heading and maturity, grain filling rate, plant height, number of spikes $/ \mathrm{m}^{2}$ and straw yield. Meanwhile Sids 12 had recorded the highest values for 1000-kernel weight and harvest index. Lower seeding rates increased number of days to heading and maturity, flag leaf area, 1000kernel weight, number of kernels/spike and harvest index. Increases of seeding rate increased plant height, number of spikes $/ \mathrm{m}^{2}$, grain and straw yields.

Differences due to interaction between seeding rates and cultivars were significant for number of days to heading in 2013/14 and highly significant for plant height and number of spikes $/ \mathrm{m}^{2}$, and significant for grain yield, straw yield and harvest index in 2012/13 growing season.

Misr 1 recorded the highest values for number of days to heading with $200 \mathrm{seeds} / \mathrm{m}^{2}$, and the tallest plant with $350 \mathrm{seeds} / \mathrm{m}^{2}$, also both Sids 12 and Misr 1 recorded the highest number of spikes $/ \mathrm{m}^{2}$ and grain yield with 350 seeds $/ \mathrm{m}^{2}$. Misr 1 produced the higher straw yield of 350 seeds $/ \mathrm{m}^{2}$. Misr 1 recorded the highest harvest index with 200 seeds $/ \mathrm{m}^{2}$ without significant different with Sids 12 at 350 seeds $/ \mathrm{m}^{2}$.
\end{abstract}

Key word: Wheat, seeding rate, cultivars, yield and yield components, and heading date.

\section{INTRODUCTION}

Wheat is the main winter cereal crop in Egypt. The production is not sufficient to meet the consumption. Therefore, developing high yielding varieties as well as improving cultural practices is necessary to solve this problem. Management practices play an important role in determining the yield and are essential to enhance wheat production and reduce importing. Wheat is grown in a wide range of environments that affect overall performance, particularly grain yield. Climatic factors 
over which producers have little control (such as precipitation, temperature, day length), soil types, and management practices (such as fertilizer, herbicides, fungicides, irrigation, time of sowing, and seeding rate) some of which may partially mitigate other environmental factors.

The differences among wheat cultivars were recorded by most researchers, e.g. Gafaar (2007), Hafez (2007), Hammad and Abdel Aty (2007) and Amin et al. (2010). These differences due to genetic back ground or the interaction with environmental conditions. Previous research's studies have shown different effects of seeding rate on the yield and its components in wheat. Mosalem (1993), Toaima et al. (2000),Allam (2005), El Hag (2006), El Hag-Dalia (2008), Ramadan and Awaad (2008), Baloch et al.(2010) and Kiliç and Gürsoy (2010) reported that increasing seed rate increased plant height, number of spikes/unit area, grain and straw yields, while it decreased kernels/spike and 1000- kernel weight. Meysam and Saeedipour (2015) reported that the seed rate significantly influenced different variables that included; spikes $/ \mathrm{m}^{2}$, number of grains/spike, 1000 kernel weight, grain yield, biological yield and harvest index. Increased seeding rate was able to increase grain yield and number spikes $/ \mathrm{m}^{2}$. However, 1000-grain weight was decreased with increasing seeding rate.

Numerous studies have documented how seeding rate, planting date, row spacing, and seeding depth affect yield and yield components of wheat. Although the effect of seeding rate on agronomic performance of cultivars is been studied since 1926 . The effect of seeding rate on the overall performance of recently released, high-yielding cultivars is unknown. Thus, it is important to evaluate the effect of seeding rate on agronomic performance of recently released cultivars. The objectives of this study were to evaluate the influence of seeding rate on agronomic performance of the two Egyptian bread wheat cultivars Misr 1 and Sids 12.

\section{Cultivars and Experimental Sites:-}

\section{MATERIALS AND METHODS}

Two field experiments were conducted in 2012/13 and 2013/14 growing seasons at Faculty of Agriculture, Kafrelsheikh University to study the effect of four seeding rates on two bread wheat cultivars. Soil of the experimental site is classified as clay textured Table 1). The field was prepared with standard production practices, such as land preparation, fertilizer application, herbicide application. Each-year the experiment was conducted as a randomized complete block design with three replications using a split plot treatment arrangement. The cultivars Sids 12 and Misr 1 (Table 2) were randomly allocated in the 
main plots and seed rate (four seeding rates were 200, 250, 300 and 350 seeds $/ \mathrm{m}^{2}$ ) randomly arranged in the sub-plots. The sub-plot area was $4.2 \mathrm{~m}^{2}$ (6 rows $\times 20 \mathrm{~cm}$ apart $\times 3.5 \mathrm{~m}$ long). The data collected were: Days to heading, days to maturity, grain filling period (day), grain filling rate $\left(\mathrm{kg} /\right.$ day/fed.), plant height $(\mathrm{cm})$, flag leaf area $\left(\mathrm{cm}^{2}\right)$, number of spikes $/ \mathrm{m}^{2}, 1000$ kernel weight $(\mathrm{g})$, number of kernels /spike, grain yield (t/fed.), straw yield (t/fed.) and harvest index (\%).

Table 1: Some physical and chemical properties of the experiment soil before sawing

\begin{tabular}{|c|c|c|}
\hline Season & $2012-2013$ & $2013-2014$ \\
\hline \multicolumn{2}{|c|}{ Mechanical analysis } \\
\hline Sand & 16.3 & 14.0 \\
Silt & 38.5 & 35.4 \\
Clay & 45.2 & 51.6 \\
Texture & clay & Clay \\
\hline Available (ppm) & \multicolumn{2}{|c|}{} \\
\hline N & 42.7 & 56.2 \\
P & 10.5 & 16.13 \\
K & 287.1 & 325.7 \\
\hline
\end{tabular}

Table 2: Name and pedigree of wheat genotypes used in this investigation

\begin{tabular}{|l|l|}
\hline Genotype & Pedigree \\
\hline Sids 12 & $\begin{array}{l}\text { BUC//7C/ALD/5/MAYA74/ON//1160.147/3/BB/GLL/4/CHAT" } \\
\text { S"/6/MAYA/VUL//CMH74A.630/4*SX. } \\
\text { SD7096-4SD-1SD-1SD-0SD. }\end{array}$ \\
\hline \multirow{2}{*}{ Misr 1 } & $\begin{array}{l}\text { OASIS/SKAUZA//4*BCN/3/2*PASTOR } \\
\text { CMSSOOYO1881T-OSOM-30Y-030M-030WGY-33M-OY- } \\
\text { OS }\end{array}$ \\
\hline
\end{tabular}

\section{Statistical analysis:}

Data collected for the two seasons were subjected to analysis of variance and means of treatment effects were compared using Duncan's Multiple Range Test (Duncan,1955). All statistical analysis was performed using analysis of variance technique by "MSTAT-C" computer software package.

\section{RESULTS AND DISCUSSION}

\section{Analysis of variance :-}

Analysis of variance of earliness and yield and it's components are presented in Table 3. 
Table 3: Estimated mean squares of earliness characters and yield components and yield for cultivars and seeding rate and their interaction in 2012/13 and 2013/14 seasons

\begin{tabular}{|c|c|c|c|c|c|c|c|}
\hline S.0.v. & D.F. & \multicolumn{2}{|c|}{ heading date } & \multicolumn{2}{|c|}{ Maturity date } & \multicolumn{2}{|c|}{ Grain filling period } \\
\hline year & & $2012 / 13$ & $2013 / 14$ & $2012 / 13$ & $2013 / 14$ & $2012 / 13$ & $2013 / 14$ \\
\hline Rep. & 2 & 0.292 & $0.875^{*}$ & 0.08 & 1.292 & 0.042 & 1.167 \\
\hline Cultivar & 1 & $24.00^{*}$ & $70.042^{\star \star}$ & $9.375^{*}$ & $28.16^{*}$ & 3.375 & 9.375 \\
\hline Error 1 & 2 & 0.373 & 0.042 & 0.373 & 1.292 & 1.125 & 1.5 \\
\hline Seed rate & 3 & $12.944^{* *}$ & $7.375^{\star *}$ & $12.486^{\star *}$ & $8.944^{\star *}$ & 0.153 & 0.819 \\
\hline $\mathrm{c} \times \mathrm{S}$ & 3 & 0.778 & $1.153^{\star \star}$ & 0.153 & 0.5 & 1.375 & 2.375 \\
\hline Error 2 & 12 & 3.333 & 0.347 & 0.236 & 0.514 & 0.472 & 0.722 \\
\hline S.O.V. & D.F. & \multicolumn{2}{|c|}{ Grain filling rate } & \multicolumn{2}{|c|}{ plant height } & \multicolumn{2}{|c|}{ flag leaf area } \\
\hline year & & $2012 / 1$ & $2013 / 14$ & $2012 / 13$ & $2013 / 14$ & $2012 / 13$ & $2013 / 14$ \\
\hline Rep. & 2 & 4.663 & 106.719 & 7.719 & $209.375^{*}$ & 1.127 & 0.335 \\
\hline cultivar & 1 & $189.7^{*}$ & 767.49 & $283059^{*}$ & $301.042^{*}$ & 17.34 & 10.938 \\
\hline Error 1 & 2 & 9.509 & 103.511 & 8.094 & 7.292 & 7.865 & 6.135 \\
\hline Seed rate & 3 & $197.2^{\star \star}$ & $254.724^{*}$ & $25.288^{\star *}$ & $14.931^{*}$ & $82.788^{* *}$ & $83.891^{\star *}$ \\
\hline $\mathrm{c} \times \mathrm{s}$ & 3 & 48.101 & 34.22 & $12.038^{\star *}$ & 3.819 & 2.648 & 0.779 \\
\hline Error 2 & 12 & 19.721 & 55.039 & 1.684 & 4.167 & 1.402 & 0.502 \\
\hline S.O.V. & D.F. & \multicolumn{2}{|c|}{ Tillers/m2 } & \multicolumn{2}{|l|}{$1000-\mathrm{kw}$} & \multicolumn{2}{|c|}{ kernel/spike } \\
\hline year & & $2012 / 13$ & $2013 / 14$ & $2012 / 13$ & $2013 / 14$ & $2012 / 13$ & $2013 / 14$ \\
\hline Rep. & 2 & 36.292 & 764.85 & 0.338 & 2.042 & 1.167 & 5.542 \\
\hline cultivar & 1 & $1666.6^{*}$ & $7783.2^{*}$ & 7.594 & $24.00^{\star *}$ & 9.375 & 7.042 \\
\hline Error 1 & 2 & 75.54 & 427.92 & 5.566 & 0.875 & 1.55 & 7.542 \\
\hline Seed rate & 3 & $3763.2^{* *}$ & 809.95 & $21.585^{\star *}$ & $10.889^{* *}$ & $21.264^{\star *}$ & $27.264^{\star *}$ \\
\hline $\mathrm{c} \times \mathrm{s}$ & 3 & $324.11^{* *}$ & 419.357 & 2.258 & 0.444 & 0.708 & 1.597 \\
\hline Error 2 & 12 & 34.58 & 260.96 & 1.903 & 0.625 & 2.111 & 0.764 \\
\hline S.O.V. & D.F. & \multicolumn{2}{|c|}{ Grain yield } & \multicolumn{2}{|c|}{ Straw yield } & \multicolumn{2}{|c|}{ Harvest index $\%$} \\
\hline year & & $2012 / 13$ & $2013 / 14$ & $2012 / 13$ & $2013 / 14$ & $2012 / 13$ & $2013 / 14$ \\
\hline Rep. & 2 & 0.009 & 0.146 & 0.166 & 0.768 & 4.919 & 12.301 \\
\hline cultivar & 1 & 0.064 & 0.552 & $2.413^{\star}$ & $5.568^{\star}$ & $23.094^{*}$ & 69.017 \\
\hline Error 1 & 2 & 0.005 & 0.076 & 0.035 & 0.101 & 0.682 & 13.519 \\
\hline Seed rate & 3 & $0.205^{\star \star}$ & $0.312^{*}$ & $1.277^{\star \star}$ & $1.450^{*}$ & 7.148 & 10.376 \\
\hline$c \times s$ & 3 & $0.077^{\star}$ & 0.02 & 0.265 & 0.037 & $15.53^{*}$ & 2.821 \\
\hline Error 2 & 12 & 0.018 & 0.073 & 0.082 & 0.339 & 3.273 & 7.401 \\
\hline
\end{tabular}

\section{Earliness measures:}

Data presented in Table 4 indicated that the differences were significant and highly significant for days to heading, significant for days to maturity and insignificant for grain filling period. Also, data in Table 6 showed significant difference in grain filling rate in the first season, significant differences on plant height in both seasons and insignificant differences on flag leaf area in both seasons between the two cultivars respectively. Sids 12 was earlier than Misr 1 cultivar needing less number of days to heading and days to maturity in both seasons. Generally, Sids 12 recorded the low attributed to their variation in genetic make-up and to the unsteady environmental condition (Shehab El-Din 1993), Geleta et al.(2002), El Hag (2006) and Soomro et al. (2009).

The data presented in Table 4 indicated that seeding rate had highly significant effect on number of days to heading, days to maturity and insignificant on grain filling period in both seasons. Increasing seeding rates decreased the number of days to heading and to maturity. An increase in seeding rate resulted in regularly more main stem, which normally flower earlier than do the secondary tillers. The greater, the proportion of main stem in the plot, the earlier the plot 
appeared to be. This results was in agreement with the finding from reduced seeding rates may also be the cause of variable and delayed maturation (Thompson et al. 1993) which in term resulted in the crop being uneven and more difficult to manage and harvest.

The interaction effect among cultivars and seeding rates was significant in the second season for days to heading Table 5. Misr 1 recorded 100 days to heading with sowing rates $200 \mathrm{seed} / \mathrm{m}^{2}$, Meanwhile Sids 12 recorded 94 days under 350 seeds $/ \mathrm{m}^{2}$.

Table 4: Mean values of number of days to $50 \%$ of heading and maturity, grain-filling period as affected by cultivars, seeding rates and their interactions in 2012/13 and 2013/14 growing seasons

\begin{tabular}{|c|c|c|c|c|c|c|}
\hline \multirow[t]{2}{*}{ Treatment } & \multicolumn{2}{|c|}{$\begin{array}{l}\text { Number of days to } \\
\text { heading (days) }\end{array}$} & \multicolumn{2}{|c|}{$\begin{array}{l}\text { Number of days to } \\
\text { maturity (days) }\end{array}$} & \multicolumn{2}{|c|}{$\begin{array}{c}\text { Grain filling period } \\
\text { (Days) }\end{array}$} \\
\hline & $2012 / 13$ & $2013 / 14$ & $2012 / 13$ & $2013 / 14$ & $2012 / 13$ & $2013 / 14$ \\
\hline \multicolumn{7}{|c|}{ Cultivars ( C ):- } \\
\hline Sids12 & $103.9 \mathrm{~b}$ & $95.9 \mathrm{~b}$ & $142.8 \mathrm{~b}$ & $140.8 b$ & 38.9 & 44.9 \\
\hline Misr1 & $105.9 a$ & $99.3 a$ & 144.1a & $143.0 \mathrm{a}$ & 38.2 & 43.7 \\
\hline F test & * & ** & * & * & NS & NS \\
\hline \multicolumn{7}{|c|}{ Seed rate $\left(\right.$ Seed $\left./ \mathrm{m}^{2}\right)$ S:- } \\
\hline 200 & $106.5 a$ & $99.0 a$ & $145.2 \mathrm{a}$ & $143.2 \mathrm{a}$ & 38.7 & 44.2 \\
\hline 250 & $105.7 \mathrm{~b}$ & $98.0 \mathrm{~b}$ & $144.0 \mathrm{~b}$ & $142.5 a b$ & 38.3 & 44.5 \\
\hline 300 & $104.3 \mathrm{c}$ & $97.0 \mathrm{c}$ & $142.8 \mathrm{c}$ & $141.7 \mathrm{~b}$ & 38.5 & 44.7 \\
\hline 350 & $103.2 d$ & $96.5 c$ & $141.8 d$ & $140.3 c$ & 38.7 & 43.8 \\
\hline F test & ** & ** & ** & ** & NS & NS \\
\hline \multicolumn{7}{|l|}{ Interaction:- } \\
\hline $\mathrm{C} \times \mathrm{S}$ & NS & * & NS & NS & NS & NS \\
\hline
\end{tabular}

Means designated by the same letter are not significantly different at $5 \%$ level according to Duncan's Multiple Range Test.

Table 5: Mean of number of days to heading in 2013/14, Plant height in $2012 / 13$ and number of fertile tillers in $2012 / 13$ as affected by the interaction between cultivar and seeding rate

\begin{tabular}{|c|c|c|c|c|c|c|}
\hline \multirow[t]{3}{*}{ Treatment } & \multicolumn{2}{|c|}{$\begin{array}{c}\text { Number of days to } \\
\text { heading (days) }\end{array}$} & \multicolumn{2}{|c|}{$\begin{array}{l}\text { Plant height } \\
\text { (cm) }\end{array}$} & \multicolumn{2}{|c|}{$\begin{array}{c}\text { Number of fertile } \\
\text { tillers } / \mathrm{m}^{2}\end{array}$} \\
\hline & Sids 12 & Misr 1 & Sids 12 & Misr 1 & Sids 12 & Misr 1 \\
\hline & \multicolumn{2}{|c|}{$2013 / 14$} & \multicolumn{2}{|c|}{$2012 / 13$} & \multicolumn{2}{|c|}{$2012 / 13$} \\
\hline \multicolumn{7}{|c|}{ Seed rate $\left(\right.$ Seed $\left./ \mathrm{m}^{2}\right)$ S:- } \\
\hline 200 & $98 \mathrm{c}$ & $100 a$ & $114 \mathrm{e}$ & $124 b$ & $351 d$ & $385 c$ \\
\hline 250 & $97 d$ & $99 \mathrm{~b}$ & $117 d$ & $125 a$ & $380 c$ & $400 c$ \\
\hline 300 & $95 \mathrm{e}$ & $99 b$ & $120 c$ & $126 a$ & $401 b$ & $417 a$ \\
\hline 350 & $94 \mathrm{e}$ & $99 b$ & $122 \mathrm{c}$ & $126 a$ & $427 a$ & $425 a$ \\
\hline $\mathrm{F}$ test & \multicolumn{2}{|c|}{ * } & \multicolumn{2}{|c|}{ ** } & \multicolumn{2}{|c|}{ *夫 } \\
\hline
\end{tabular}

Means designated by the same letter are not significantly different at $5 \%$ level according to Duncan's Multiple Range Test.

Data presented in Table 6 indicated significant difference between the two cultivars in grain filling rate in the first season, 
significant differences on plant height in both seasons and insignificant differences on flag leaf area in both seasons. Generally, Sids 12 recorded the lowest values in grain filling rate and plant height as compared with Misr 1. Regarding seeding rate the data in Table 6 indicated highly significant and significant effect on grain filling rate and highly significant and significant on plant height and highly significant on flag leaf area in both seasons, respectively. Increasing seed rate increased positively grain filling rate and plant height and decreased flag leaf area.

Table 6: Mean of grain filling rate, plant height and flag leaf area as affect by cultivars, seeding rate (seeds $/ \mathrm{m}^{2}$ ) and their interaction in 2012/13 and 2013/14 growing seasons

\begin{tabular}{|c|c|c|c|c|c|c|}
\hline \multirow[t]{2}{*}{ Treatment } & \multicolumn{2}{|c|}{$\begin{array}{l}\text { Grain filling rate } \\
\text { (kg/day/fed.) }\end{array}$} & \multicolumn{2}{|c|}{$\begin{array}{l}\text { plant height } \\
(\mathrm{cm})\end{array}$} & \multicolumn{2}{|c|}{$\begin{array}{c}\text { flag leaf area } \\
\left(\mathrm{cm}^{2}\right)\end{array}$} \\
\hline & $2012 / 13$ & $2013 / 14$ & $2012 / 13$ & $2013 / 14$ & $2012 / 13$ & $2013 / 14$ \\
\hline \multicolumn{7}{|c|}{ Cultivars ( C ):- } \\
\hline Sids12 & $118.47 b$ & 97.59 & $118.4 b$ & $109.6 b$ & 33.8 & 32.4 \\
\hline Misr1 & $124.10 a$ & 108.99 & $125.3 a$ & $116.7 a$ & 35.5 & 33.8 \\
\hline F test & * & NS & * & * & NS & NS \\
\hline \multicolumn{7}{|c|}{ Seed rate $\left(\right.$ Seed $\left./ \mathrm{m}^{2}\right)$ S:- } \\
\hline 200 & $114.00 \mathrm{c}$ & $96.49 \mathrm{c}$ & $118.9 b$ & $110.8 \mathrm{~b}$ & $38.9 a$ & $37.6 a$ \\
\hline 250 & $120.05 b$ & $99.31 \mathrm{bc}$ & $121.8 \mathrm{a}$ & $113.3 a b$ & $36.3 b$ & $34.2 b$ \\
\hline 300 & $123.58 \mathrm{ab}$ & 106.47ab & $123.0 \mathrm{a}$ & $114.2 \mathrm{a}$ & $32.8 \mathrm{c}$ & $31.7 c$ \\
\hline 350 & $127.51 \mathrm{a}$ & $110.72 a$ & $123.5 \mathrm{a}$ & $114.2 \mathrm{a}$ & $30.5 d$ & $28.8 d$ \\
\hline F test & ** & * & ** & * & ** & ** \\
\hline \multicolumn{7}{|l|}{ Interacti } \\
\hline $\mathrm{C} \times \mathrm{S}$ & NS & NS & ** & NS & NS & NS \\
\hline
\end{tabular}

Means designated by the same letter are not significantly different at $5 \%$ level according to Duncan's Multiple Range Test.

Generally increasing seed rate increased plant height due to increased competition affected plant height at the highest seeding rate (which also shortened tillers length). The results are in agreement with those of Stapper and Fischer (1990), Geleta et al. (2002), El Hag (2006), Soomro et al. (2009), Kiliç and Gürsoy (2010) and Saad (2010). The interaction effect between cultivars and seed rates was highly significant on plant height in the second season only (Table 4). Misr 1 recorded the tallest plant under 300 and $350 \mathrm{seed} / \mathrm{m}^{2}$ while Sids 12 recorded the shortest one under $200 \mathrm{seed} / \mathrm{m}^{2}$ Table 5 . Generally increasing seed rate increased plant height due to increased competition affected plant height at the highest seeding rate (which also shortened tillers length). The results are in agreement with those of Stapper and Fischer (1990), Geleta et al. (2002), El Hag (2006), Soomro et al. (2009), Kiliç and Gürsoy (2010) and Saad (2010). 


\section{Yield components:}

In both seasons, data presented in Table 7 indicated that the differences among the two cultivars were significant for number of spikes $/ \mathrm{m}^{2}$, as well as, Significant differences for 1000 kernels-weight in the $2^{\text {nd }}$ season, and insignificant for number of kernels/spike in both seasons. Misr 1 produced the highest number of spikes $/ \mathrm{m}^{2}$ (407 and 463), as compared with Sids 12 (390 and 427) in the first and second seasons respectively. Sids 12 recorded the highest values of 1000 kernel weight $(40.8 \mathrm{~g})$ in the second season. Our results are in contrast with Geleta et al. (2002), Patrick et al. (2003) Abu-Grab et al. (2006), Baloch et al.(2010) Hussain et al. (2010) and Kiliç and Gürsoy (2010).

Regarding seeding rate, the results Table 7 showed highly significant effect on number of spikes $/ \mathrm{m}^{2}$, in the first season only, and highly significant effect on 1000-kernel weight and number of kernels/spike in both seasons. Increase of seeding rate from 200 to 350 seeds $/ \mathrm{m}^{2}$ increased gradually number of spikes from 368 to 426 spikes $/ \mathrm{m}^{2}$ and decreases 1000-kernel weight from 44.9 and 41 to 40.3 and $38 \mathrm{~g}$, and decreased number of kernels /spike from 67 and 64.2 to 62.5 and 59.2 in both seasons, respectively. Obtained results are in good accordance with those previously reported by Ali et al. (2004), Soomro et al. (2009), Baloch et al.(2010) and Kiliç and Gürsoy (2010). The increases in number of fertile tillers were due to increase in numbers of seeds per unit area. On the same time the decreases in 1000-kernel weight and number of kernels/spike were due to the competition on nutrient in soil, moisture, air and light.

Table 7: Mean of number of fertile tillers, 1000-kernel weight $(\mathrm{g})$ and number of kernels /spike as affect by cultivars, seeding rate and their interaction on in 2012/13 and 2013/14 growing seasons

\begin{tabular}{|c|c|c|c|c|c|c|}
\hline \multirow[t]{2}{*}{ Treatment } & \multicolumn{2}{|c|}{$\begin{array}{l}\text { Number of } \\
\text { spikes } / \mathrm{m}^{2}\end{array}$} & \multicolumn{2}{|c|}{$\begin{array}{c}\text { 1000- kernels } \\
\text { weight }(\mathrm{g})\end{array}$} & \multicolumn{2}{|c|}{$\begin{array}{c}\text { Number of } \\
\text { kernels/spike }\end{array}$} \\
\hline & $2012 / 13$ & $2013 / 14$ & $2012 / 13$ & $2013 / 14$ & $2012 / 13$ & $2013 / 14$ \\
\hline \multicolumn{7}{|c|}{ Cultivars ( C ):- } \\
\hline Sids12 & $390 \mathrm{~b}$ & $427 b$ & 43.1 & $40.8 \mathrm{a}$ & 65.4 & 61.2 \\
\hline Misr1 & $407 a$ & $463 a$ & 41.9 & $38.8 b$ & 64.2 & 62.3 \\
\hline$F$ test & * & * & NS & * & NS & NS \\
\hline \multicolumn{7}{|c|}{ Seed rate $\left(\mathrm{Seed} / \mathrm{m}^{2}\right)$ S:- } \\
\hline 200 & $368 d$ & 433 & $44.9 a$ & $41.0 \mathrm{a}$ & $67.0 \mathrm{a}$ & $64.2 \mathrm{a}$ \\
\hline 250 & $390 c$ & 437 & $42.8 b$ & $40.7 a$ & $65.3 \mathrm{ab}$ & $62.5 b$ \\
\hline 300 & $409 b$ & 453 & $42.0 \mathrm{bc}$ & $39.7 b$ & $64.3 b$ & $61.0 \mathrm{c}$ \\
\hline 350 & $426 a$ & 456 & $40.3 c$ & $38.0 \mathrm{c}$ & $62.5 \mathrm{c}$ & $59.2 d$ \\
\hline $\mathrm{F}$ test & ** & NS & ** & ** & ** & ** \\
\hline \multicolumn{7}{|c|}{ Interaction: - } \\
\hline $\mathrm{C} \times \mathrm{S}$ & ** & NS & NS & NS & NS & NS \\
\hline
\end{tabular}

Means designated by the same letter are not significantly different at $5 \%$ level according to Duncan's Multiple Range Test. 
The interaction effect among cultivars and seed rates were highly significant effect on number of spikes $/ \mathrm{m}^{2}$ in the second season only. Sids 12 produced the highest number of spikes (427) with sowing with 350 seeds $/ \mathrm{m}^{2}$. On the other hand Misr 1 produced 417 and 425 spikes with sowing of 300 and 350 seeds $/ \mathrm{m}^{2}$ without significant with Sids 12 (Table 5).

\section{Yield:-}

Data in Table 8 indicated that insignificant deference's existed between the two cultivars for grain yield, but significant differences on straw yield in both growing seasons and harvest index in the first season. Where Misr 1 recorded the highest values of straw yield ( 5.829 and $5.266 \mathrm{t} / \mathrm{fed}$.) in the first and second seasons, respectively. Sids 12 recorded the highest harvest index (42.5\%) in the first season. Obtained results are in good accordance with those previously reported by Saleh (2000), Geleta et al. (2002) El Hag (2006) and Kiliç and Gürsoy (2010).

Table 8: Grain yield ( $\mathrm{t} / \mathrm{fed}$ ), straw yield ( $\mathrm{t} / \mathrm{fed}$ ), and harvest index\% as affected by wheat cultivars, seeding rate and their interaction in 2012/13 and 2013/14 growing seasons

\begin{tabular}{|c|c|c|c|c|c|c|}
\hline \multirow[t]{2}{*}{ Treatment } & \multicolumn{2}{|c|}{$\begin{array}{c}\text { Grain yield } \\
\text { (t/fed.) }\end{array}$} & \multicolumn{2}{|c|}{$\begin{array}{l}\text { Straw yield } \\
\text { (t/fed.) }\end{array}$} & \multicolumn{2}{|c|}{$\begin{array}{c}\text { Harvest index } \\
\%\end{array}$} \\
\hline & $2012 / 13$ & $2013 / 14$ & $2012 / 13$ & $2013 / 14$ & $2012 / 13$ & $2013 / 14$ \\
\hline \multicolumn{7}{|c|}{ Cultivar ( C ) } \\
\hline Sids12 & 3.843 & 3.654 & $5.195 b$ & $4.305 b$ & $42.5 a$ & 45.9 \\
\hline Misr1 & 3.946 & 3.957 & $5.829 a$ & $5.268 a$ & $40.4 b$ & 42.9 \\
\hline $\mathrm{F}$ test & NS & NS & * & * & * & NS \\
\hline \multicolumn{7}{|c|}{ Seed rate $\left(\right.$ Seed $\left./ \mathrm{m}^{2}\right) \mathrm{S}:-$} \\
\hline 200 & $3.673 c$ & $3.550 b$ & $4.843 b$ & $4.383 b$ & 43.1 & 44.7 \\
\hline 250 & $3.834 \mathrm{bc}$ & $3.680 \mathrm{ab}$ & $5.576 a$ & $4.353 b$ & 40.7 & 45.8 \\
\hline 300 & $3.963 a b$ & $3.959 a$ & $5.778 \mathrm{a}$ & $5.091 \mathrm{ab}$ & 40.7 & 43.7 \\
\hline 350 & $4.107 a$ & $4.033 a$ & $5.852 a$ & $5.318 a$ & 41.2 & 43.1 \\
\hline$F$ test & ** & * & $* *$ & $\star$ & * & NS \\
\hline \multicolumn{7}{|l|}{ Interaction } \\
\hline $\mathrm{C} \times \mathrm{S}$ & * & NS & * & NS & * & NS \\
\hline
\end{tabular}

Means designated by the same letter are not significantly different at $5 \%$ level according to Duncan's Multiple Range Test.

Regarding seeding rates (Table 8), the results showed highly significant and significant effect, on grain and straw yield in both seasons, respectively and on harvest index in the first season only. The highest grain yield was obtained by increasing seeding rate from 200 to $350 \mathrm{seed} / \mathrm{m}^{2}$ which increased grain yield from 3.963 and 3.55 to 4.107 and $4.033 \mathrm{t} / \mathrm{fed}$ ) and straw yield from 4.843 and 4.383 to 5.852 , 
and $5.318 \mathrm{t} / \mathrm{fed}$. In the first and second season, respectively. Meanwhile, harvest index was decresed by increasing seeding rate. These results are in agreement with those of Allam (2005), El Hag (2006), El Hag-Dalia (2008), Ramadan and Awaad (2008), Baloch et al..(2010) and Kiliç and Gürsoy (2010).

The interaction effect between cultivars and seeding rates on grain yield, straw yield and harvest index were significant in the first season (Table 9). Sids 12 and Misr 1 produced 4.13 and $4.09 \mathrm{t} / \mathrm{fed}$ ) grain. Meanwhile, Misr 1 produced the highest straw yield with sowing of 350 seeds $/ \mathrm{m}^{2}$ and recorded the highest harvest index with sowing of 200 seeds $/ \mathrm{m}^{2}$.

Table 9: The interaction effect of seeding rate and cultivars on grain yield, straw yield and harvest index in 2012/13 season

\begin{tabular}{|c|c|c|c|c|c|c|}
\hline & \multicolumn{2}{|c|}{$\begin{array}{c}\text { Grain yield } \\
\text { (t/fed) }\end{array}$} & \multicolumn{2}{|c|}{$\begin{array}{l}\text { Straw yield } \\
\text { (t/fed) }\end{array}$} & \multicolumn{2}{|c|}{$\begin{array}{c}\text { Harvest index } \\
\%\end{array}$} \\
\hline & Sids 12 & Misr 1 & Sids 12 & Misr 1 & Sids 12 & Misr 1 \\
\hline \multicolumn{7}{|c|}{ Seed rate $\left(\right.$ Seed $\left./ \mathrm{m}^{2}\right) \mathrm{S}:-$} \\
\hline 200 & $3.45 c$ & $3.89 a b$ & $4.81 d$ & $4.87 \mathrm{~cd}$ & $41.77 a b$ & $44.46 a$ \\
\hline 250 & $3.83 b$ & $3.84 b$ & $5.26 \mathrm{~cd}$ & 5.89ab & $42.15 a b$ & $39.51 \mathrm{~b}$ \\
\hline 300 & $3.97 a b$ & $3.96 a b$ & $5.38 b c$ & $6.17 \mathrm{a}$ & $42.42 a b$ & $39.12 b$ \\
\hline 350 & $4.13 a$ & $4.09 a b$ & 5.32cd & $6.38 a$ & $43.67 a$ & $39.07 b$ \\
\hline $\mathrm{F}$ test & & & & & & \\
\hline
\end{tabular}

Means designated by the same letter are not significantly different at $5 \%$ level according to Duncan's Multiple Range Test.

\section{REFERENCES}

Abu-Grab, O. S., A. M. Moussa and G. A. El-Shaarawy (2006). Photosynthetic and N-use efficiencies for some wheat cultivars in relation to planting density and nitrogen fertilization level. Egypt. J. Appl. Sci., 21(2B):475-492.

Ali, A. G. A., O. E. Zeiton, A.H. Bassiouny and A.R.Y. El-Banna (2004). Productivity of wheat cultivars grown at El-Khattara and ElArish under different levels of planting densities and $\mathrm{N}$ fertilization. Zagazig J. Agric. Res., 31(4A):1225-1256.

Allam, S.A. (2005). Growth and productivity performance of some wheat cultivars under various nitrogen fertilization levels. J. Agric. Sci., Mansoura Univ., 30 (4):1871-1880.

Amin, E. H. M. , A. A. Ibrahem, M.E. Saleh and A.G.A. Ali (2010). Response of wheat cultivars to varing time of $\mathrm{N}$-application, planting densities and sowing date. Zagazig J. Agric. Res., Vol. 37 No. (4):803-828.

Baloch, M. S, T. H. Shah, M. A. Nadiam, M.A. Khan and A. A.Khakan (2010). Effect of seeding density and planting time on growth and yield attributes of wheat. J. Anim. Plant Sci. 20(4):239-243. 
El-Hag, A.A. (2006). The influence of seeding rate on yield and its components of some Egyptian wheat cultivars. J. Agric. Res., Tanta Univ., 32(1). 76-89.

El-Hag, Dalia A. (2008). Effect of nitrogen fertilizer rate on productivity and quality of some wheat cultivars under different plant densities M.Sc. Thesis, Kafr EL-Sheikh Univ., Egypt.

Gafaar, N. A. (2007). Response of some bread wheat varieties grown under different levels of planting density and nitrogen fertilizer. Minufiya J. Agric., Res., 32(1): 165-183.

Geleta, B, M. Atak, P. S. Baenziger, L. A. Nelson, D. D. Baltenesperger, K. M. Eskridge, M. J. Shipman and D. R. Shelton (2002). Seeding rate and genotype effect on agronomic performance and end use quality of winter wheat. Crop Sci.42:827-832.

Hafez , E. M. (2007). Effect of some agricultural practices on growth and productivity of wheat. M.Sc. Thesis, Fac. Agric., Kafr El-Sheikh Univ., Egypt.

Hammad, S.A. and M.S.M. Abd El-Aty (2007). Diallel analysis of genetic variation for earliness and yield and its components in bread wheat. J. Agric. Res., Kafr El-Sheikh Univ., 33(1):88-100.

Hussain, I., M. A. Khan, and H. Kahan(2010). Effect of seed rates on the agro-physiological traits of wheat. Sarhad j. Agric. 26(2):169-176

Kiliç, H., and S. Gürsoy (2010). Effect of seeding rate on yield and yield components of durum wheat cultivars in cotton-wheat cropping system. Scientific Research and Essays. 5(15):2078-2084.

Meysam B and S. Saeedipour (2015). Effect of seed rate and post emergence herbicide application on weed infestation and subsequent crop performance of wheat (Triticum aestivum L.). WALIA journal 31(3): 158-162.

Mosalem, M. E. (1993). Response of two bread wheat cultivars to nitrogen level and seeding rate. J. Agric. Res., Tanta Univ., 19(4),792-805.

MSTATC, (1990). A Microcomputer program for Design Manegment and Analysis of Agronomic Research Experiments Michigan State Univ.

Patrick M. C, R. D. Horsleyb and W. W. Polanda (2003). Tillage and Seeding Rate Effects on Wheat Cultivars II. Yield Components CSSA 43:50 kg/fed-218

Ramadan, A. R. and S. S. Awaad (2008). Response of yield and yield attributes of some bread wheat varieties to irrigation levels and seeding rate under old land conditions. J. Agric. Sci., Mansoura Univ., 33(7) : 4717-4737.

Saad, A. Sulieman (2010). The influence of Triticum Asetivum Seeding Rates and Sowing Patterns on the Vegetative Characteristics in Shambat Soil under Irrigation. Res. J.Agric.\& Biot.Sci. 6(2): 93102.

Saleh, M. E. (2000). Effect of seeding rate on yield, yield component and some agronomic characters of two bread wheat cultivars. J. Agric. Sci., Mansoura Univ., 25 (3): 1467- 1473. 
Shehab El-Din, T.M. (1993). Response of two spring wheat cultivars ( $T$. aestivum L. em Thell), to ten seeding rates in sandy soil. J. Agric. Sci., Mansoura Univ. 18 (8): 2235-2240

Soomro, U. A., M. Ur Rahman, E. A. Odhano, S. Gul, A. Q. Tareen (2009). Effects of Sowing Method and Seed Rate on Growth and Yield of Wheat (Triticum aestivum).World Journal of Agricultural Sciences 5 (2): 159-162

Stapper, M., and R. A. Fischer (1990). Genotype, sowing date and plant spacing influence on high-yielding irrigated wheat in southern New South Wales. I. Phasic development, canopy growth and spike production. Aust. J. Agric. Res. 41:997-1019.

Thompson, A. J., M. J. Gooding, and W.P. Davies (1993). The effect of season and management on the grain yield and bread making quality of organically grown wheat cultivars . p. 179-188. In Aspects of applied biology 36, Cereal Quality III. Association of Applied Biologists, Warwick, UK.

Toaima, S. E. A., Amal A. El-Hofi and H. Ashoush (2000). Yield and technological characteristics of some wheat varieties as affected by $\mathrm{N}$ fertilizer and seed rates. J. Agric. Sci., Mansoura Univ., 25 (5): 2449- 2467.

Wilson, J. A., and A. F. Swanson (1962). Effect of plant spacing on the development of winter wheat. Argon. J. 54:327-328.



اجريت تجربتان حقليتان فى المزرعة البحثية بكلية الزراعة - جامعة كفر الثيخ فى موسمى (200)

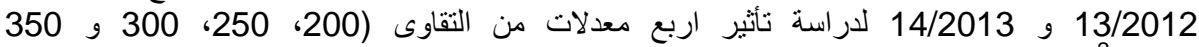

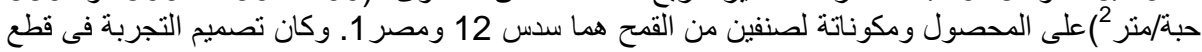

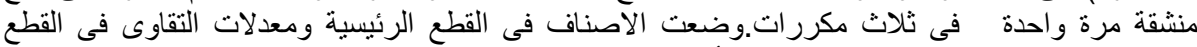

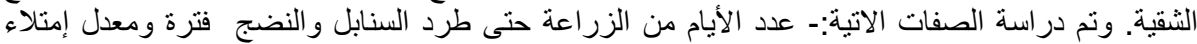

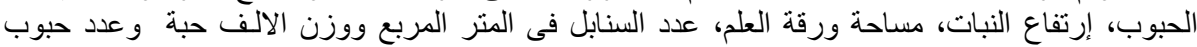



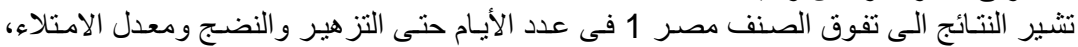

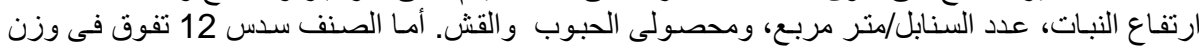

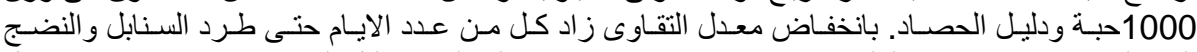

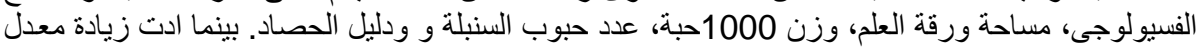

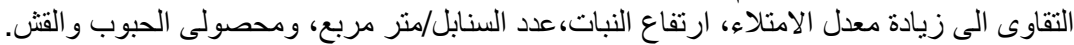

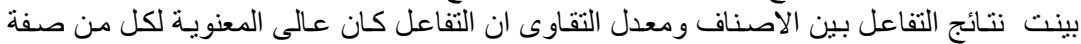

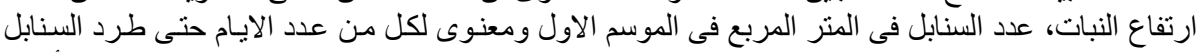

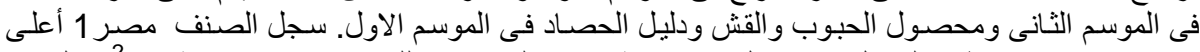

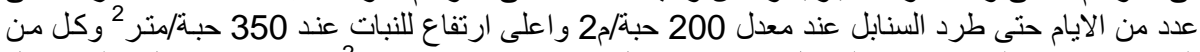

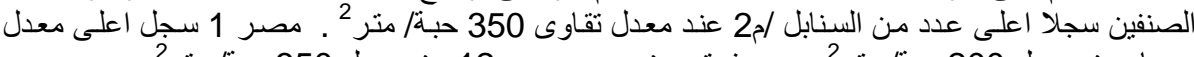

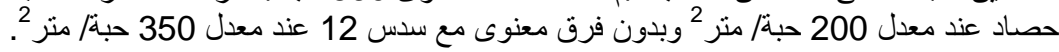

